\title{
Albanian and English Literature in Light of Comparative Reports
}

\author{
Dr. Vjollca Dibra \\ Dardania School \\ E-mail: dibravjollca@gmail.com
}

\section{Doi:10.5901/ajis.2012.v2n4p79}

\section{Abstract:}

In light of comparative literature studies, relations between English Literature and Albanian Literature have been treated little and partially. Furthermore, to date, these studies almost never exceeded the level of monitoring and papers, and no monographic and panoramic level. In this regard, in my thesis, I will emphasize and analyze the relations:

- Short history of relations between the two literatures;

- Critical literary and historic-literary opinion about these relations;

- Kadare's approach on Shakespeare, Joyce and Orwell;

- Similarities, influences and contextual basis;

- The prospect of Albanian-English literary developments in terms of giving and receiving.

Relations between the two literatures will be seen increasingly on the basis of comparative literature, targeting works and representative personalities of both sides, the respective literatures, as in literary-historical field, as well as in literary-theoretical field. Obviously critical and theoretical thinking on literature (Albanian as well as English) determines and reflects the cooperative levels between them, but the comparative methodology in a way sets a hierarchy of values, knowledge and recognition between them. The most significant of these literary relations today is especially the mutual translation.

\section{Introduction}

While we can say without hesitation that historians, theorists, and aesthetes of Albanian literature represent a constellation, by even making a class or a thin layer of what may be called tradition, comparative scholars can be listed only by counting the fingers, if as such we consider even the lecturing professors of this subject in all Albanology centres of Balkans.

However indications of pioneers, though not in level of studies, at least at the level of observation, probe or review, can also be found within the Albanian literature, beginning with De Rada to Konica, Noli, Kuteli etc. Such reflections are also encountered in Kosovo within the corpus of literature-history studies of the academic Rexhep Qosja (having in consideration his studies for the period of Romantics as a literature-stylistics establishment of the Albanian literature and the parallels with European Romantics). An obvious effort was also made by scholars like: Dr. Mensur Raifi and Dr. Rexhep Ismaili, at outlining the works of Lasgush Poradeci with Mihaj Eminesku, followed by Dr. Abdullah Karjagdiu with the monographic study Byron and Albanians to Dr. Luan Starova with the book "An eternal amity" (Konica - Apolineri).

In the horizon we may also see first indicators of the results of young researchers and scholars like Yllka Kenaci, specifying here a work that draws a parallel between the novel "Dream palace" of Kadare and Kafka's "Process", Kadri Ujkaj with his work "Modern intersection of geniuses" (comparative study between Kadare and Migjen), doc. Rusana Hristova-Bejleri from Sofia University, who we may say to have deepened the knowledge and the methodology in this subject with hear multilateral treatment of comparative literature science at studying the Albanian literature. She is right to assert that "if we refer to the merest methodology definition "the comparative literature science compares, exceeds limits and uses patterns", and it sheds light to the case of the Albanian literature where such a minimum of actions gives a hand to comparison amongst the Albanian speaking communities belonging to different states, but also to compare it with the abroad. In 
general the character of a comparison may be a concluding or qualifying one, and when it is qualifying it may be either positive or negative" (http://www.bnr.bg/sites/sq/culture).

I would also add the fact that they may be affirming or denying, sustainable or unsustainable, but, in any variant having particular importance and significance.

My opinion on this basis of comparative studies within the Albanian literature is that makes me insist that it is relatively new and yet unexplored, in particular when we speak about novel, but it moves when taking into consideration the contemporary developments, when the rhythm of Albanian studies for literature (in particular for the comparative literature) is accelerating in the aspect of methodology specifics, and also in the persuasion of postmodern considerations, according to conceptual principles. Nowadays, it does not present a surprise in the centres of Albanalogy study, and not even to individuals or groups of Albanian scholars when mentioning a name like Linda Haçion, a Canadian scholar that is a member of the postmodernism theoreticians' constellation.

So, should we consider it in the aspect of liaisons and comparisons of Albanian literature to the English literature, it results that their relations are to be researched. The word "composite", relation, represents a quantity of receiving and giving. This relation phenomenon must be viewed in the context of knowledge of mutual information in various periods of time. The entirety of this methodological aspect may be formulated as a short history of relations between the two literatures.

The phenomenon of recognition between the two, results also with critical opinions and estimations of respective literature values, therefore we are going to observe within this context the Literature critic and literature history opinion related to these relations.

Bearing in mind that the literature of one people, of a country or of a language is usually marked by literature representation authorities, there is no possibility of avoiding in this sense Shakespeare, Byron, Joyce and Orwell in relation to Kadare, therefore the latter should indeed be seen in the relation to the English predecessors: Kadare in comparison to Shakespeare, Joyce, Orwell.

Just as it was mentioned above, the relations do not have to deal only with recognition, but also with similarities, diversities and influences in various time and space contexts: Similarities, influences and contextual basis.

Such analysis consequently leads to the direction of Perspective of Albanian-English literature developments in receiving and giving relations.

\section{A short history of relations between the two literatures}

Although the English Literature is a developed literature and has impact in the global dimension (considering the distribution of the English language in the world), it cannot be said that in relation to Albanian Literature (as a small literature of a small language, though it belongs to Indo-European trunk) it recognizes any "bloom" of relations. In this regard, among other things, the implications of the difficult fate of its literature, which for over half a century experienced the censorship of the socialist Realism literary school, even in its most severe and rude version.

However, the major English literary authors, i.e. their literary works came to the Albanian areal much earlier through alternate routes rather than directly, in Albanian language.

Since, for example, De Rada is a major figure of Albanian literature that leads Albanian Romanticism and marked contemporaneity with European developments (remember his work named Milosao from 1836, a full century before Kadare and Qosja were born), it is worth studying how he stands in relation to the English literature. His biographical and autobiographical notes tell us that he knew many English authors, but we should emphasize the works of Shakespeare and Byron. Furthermore, for the work of Byron, by feeling coeval with him, he will write: In the next year I was able to get hold of Byron's "Corsair", who, along with Alfieri, was ushered into heaven. I was impressed especially with the newness and greatness of figures, but he seemed to me like someone from Lukani school, who does not know how to draw people's features as vivid from actions 
and sayings, but tries to devise them by describing and collecting the features. (De Rada, WORKS 7, "Rilindja, Prishtine 1988, p. 301).

Here he proves that not only does he not feel inferior, but, furthermore has the courage to be judgemental and critical of Byron.

In this context of autobiographical notes, by referring to his readings, which affect his formation as a writer, he mentions that ... in order to be immersed in modern literature the French language, which I learned in two months from the lectures of my generous friend, enabled me to read Shakespeare, Schiller ... The impression that Shakespeare gave me, in terms of style, never got out of my mind. He expressed such powerful feelings, but it seemed to me that he did that after having gone through these things real good in his head. (De Rada, ibidem. p. 304).

From these data, no matter how slim, for the first time we see the presence of English literature in the Albanian world, despite its arrival even through intermediate languages.

In the Albanian culture and literature Shakespeare comes more complete with his masterpieces, especially in the thirtieths Othello, Hamlet, Macbeth, and Julius Caesar, have come through Fan Noli. In this way, Noli also brought in Albanian the Skanderbeg of Lonfellou, Edgar Allen Poe's works, as well as other works. Skënder Luarasi successfully pursued Noli's path, by bringing to Albanian territory Milton's Lost Paradise, Byron's Childe Harold, and other. Later on also the works of Sheli and Bernard Shaw were brought in Albanian, and later those of Eliot, Ezra Pound and Ted Hughes and, much later, came Oscar Wilde, Orwell and James Joyce.

An important place of the presence of Bernard Shaw in Albanian literature was introduced to us by the scholar, Prof. As. Dr. Lirak Karjagdiu: "The works of this colossus of world papers have been translated into many world languages, while they were translated into Albanian language in the 50's. Thus in 1956, Vedat Kokona, our renowned translator, translated two of the most popular Shaw's dramas "Major Barbara" and "Pigmalion". Also, in 1972, two of the Shaw's comedies were translated: "American Emperor" translated by Sylejman Pitarka and "Houses of Widowed Men" translated by Bashkim Pitarka, etc. While, not long ago, in the edition of Skanderbeg Books Publishing House in Tirana, came to light the melodrama of Bernard Shaw "Devil worshiper". In this case, it is worth noting that there are two versions of the translation of this Shaw's drama. It was translated for the first time in Kosovo by the translator, researcher, polyglot and our well known professor Dr. Abdullah Karjagdiu, in the 80's, while the second translation was done in Albania in 2006, by our well known and experienced translator Afrim Karagjozi. It is worth noting that the translation of dramas of this playwright and Nobel Prize winner has started during the 80's when Prof. Dr. Abdullah Karjagdiu translated four of the Shaw's dramas: "Candida", "Devil's Disciple", " Ms. Warren's Profession " and "Androcles and the lion." (http://www.academia.edu/859125/George_Bernard_Shaws_Presence_In_Albanian)

In the feedback report it is almost impossible to find titles and even more difficult translations from Albanian into English. An incomplete attempt was made by Arshi Pipa for Kadare's Chronicle in Stone, which ended with a fight between the British publisher and the translator regarding the preface for the latter.

In 1991, the editor Mensur Raifi published The Anthology of Albanian stories in Yugoslavia, THE ANGRY CLOUD, translated by John Hodgson, (The Angry Cloud - And Anthology of Albanian Stories from Yugoslavia, Translated from the Albanian by John Hodgson), which included nine authors: Anton Pashku, Hivzi Sulejmani, Azem Shkreli, Eqrem Basha, Ymer Shkreli, Musa Ramadani, Ramiz Kelmendi, Adem Gashi and Rifat Kukaj.

It cannot go unnoticed that this translator, John Hodgson, after full two decades brings Kadare's novel Wrong Dinner into English directly from Albanian and this year it is this novel that competes for the Literary prize there.

At this point we cannot ignore another interesting information. Two foreign scholars whose works are not only valued and admired, but also have become points of reference in contemporary studies and in Anglophone areas in particular, the historian Noel Malcolm and researcher Robert Elsie with his History of Albanian Literary (History of Albanian Literature by Robert Elsie, Social Science Monographs, Boulder. Distributed by Columbia University Press, New Uork 1995). 
Needless to say, in a paper of this nature, it is impossible to include all literary materials that can be recorded as making or rendering. There are also numerous contributions of authorial nature and private publications of various authors that often result as not catalogued by the Albanian national libraries. There are also numerous articles in the form of memoirs, travel descriptions and of other cultural nature, such as the work of Edith Durham Burden of the Balkans, and other works for Albania and Albanians, which do not directly reflect the literary terrain.

\section{Literary critical and historical-literary thinking regarding these relations}

Of the Albanian scholars, obviously academic Rexhep Qosja, literary historian by vocation, is one of the first that studied the relationship between Albanian and English literatures, but more in the receiving and affective aspect. Thus, while analyzing the period of Romanticism in Albanian literature, he, among other things investigates Albanian writers' interests in foreign literatures since the ancient era and onwards. Among these, in a subchapter he highlights the Interest in English literature. Though there is no lack of interest, such as the interest of De Rada, Naim and Mjeda, compared to, say, the interest in French literature, they appear much more modest. The English authors mentioned in the writings of our Romanticists are usually rarely mentioned, only one or two times. Thus, for example, Jeronim de Rada mentions Shakespeare, Naim Frasheri, mentions Milton, and Ndre Mjeda, mentions the Irish poet, Charles Wolf. The only English poet that is mentioned by nearly all of our romanticists and the only English poet that is often mentioned, almost as much as Homer, is Byron. (Qosja. Rexhep, HISTORY OF ALBANIAN LITERATURE, Romanticism I. "Rilindja", Prishtinë 1990, p. 91).

Qosja certainly, as well as all other scholars, explains the interest of Albanian writers for Byron, first of all due to his pilgrimage at the beginning of the XIX century across Albanian areas, due to his relationship with Ali Pasha Tepelena and particularly due to his artistic evaluation for the Albanian world in the poem Childe Harold.

Byron, through Albanian writers, became so popular that, despite social orders of other environments, was almost always part of the school literature as a compulsory text, as a reading material. There is almost no generation of Albanian students, who have gone through primary and secondary education, who have not memorized at least some verses of the second Song, such as:

Oh Albania, where bore Iskander -

Song of youth', lantern of wise men! -

And the other Iskanderi, which permanently

Thrashed the enemies with its heroic Kordhn':

Albania, allow me to restore my eyes'

Upon you, oh strict mother of wild men! ....

(Bajroni, Childe Harold, Onufri, Tirana 1999, p. 48).

Scholar Abdullah Karjagdiu, who is the first one in our institution with a dissertation in English Language and Literature, who, while writing these days has reminded us that it is through Byron that Europe heard the name Albanian after four centuries: "For the young Byron, though officially he was visiting the Ottoman Empire, in fact he was interested in Albanians, their country, history and their characteristics. He ... during his peregrination tarried mountains, spent nights in cabins and mansions, praised the generosity, hospitality and their respect, by mentioning them in the twenty five letters he sent to his mother and friends ...(http://noa.al/news/artikull.php?id=30660).

Fan Noli, being a multifaceted Albanian figure, apart from the merit of turning Shakespeare's plays and many other culminating works of world literature into Albanian, he also enjoys the privilege of critical contemplation of those works, without claiming the work as a critic and scholar of literature. Yes, in fact, a part of Introductions, - as he calls his prefaces that accompany his translated works, are primarily sharp critical views. While we are highlighting the English Literature, we cannot transcend Noli's exquisite observation 
about Shakespeare's Macbeth: "It is the tragedy of criminal ambition, sin and fusion not in the Hell of another life, but in the Hell of this life, and in this respect this is the deepest, strongest and most terrifying religious sermon that was preached by an Anglo-Saxon priest since Christianity was born and until today. The Theme is: Selfish ambition without scruple, without mercy and without consciousness is the adder that eats itself and creates the Hell over the Ground for its master, more dreadful than that of the medieval religious poet Dante ... Shakespeare's Hell is not based on controversial dogma but on facts, proven by life experience..." (Shakespeare, William, MACBETH, "Rilindja", Prishtina 1968, p. 8-9).

While we are here we can emphasize a matter that has recently been brought up in different presentations. It has to do with the level and value of Noli's translations. There are people who say that they are outdated and do not meet today's standards (Writer and translator Agron Tufa has broken a taboo. During an interview for the the 'Albanian Journal' about the supplement 'Milosao' he has revealed that Fan Noli's translations should be reviewed, re-translated, to be saved by a number ideologies and folklores that can be encountered in the translated texts, classics, and in their prefaces. Tufa, himself a translator, said that a good part of the classics, if not all, should be re-translated.28 November, 2011).

Of course, such an idea shouldn't be ignored, but since we have no practical evidence or even attempts in this field, nor any effort of re-translating these masterpieces of world literature, such reaction, however sounds sturdy, swagger and biased.

Parenthesis: In this respect it should be noted that in the languages and literatures of the people with tradition, there is a practice that the renowned works are simultaneously translated by two or more translators and only then the work is characterized and valued as a competition. In Albanian several versions of translation are recognized, for example, Adam Mitskevich's poems by Lasgush Poradeci and Kadare. In Kosovo once they tried a simultaneous translation of Guillaume Apollinaire's renowned poem "Mirabeau Bridge" in the pages of the magazine "Fjala" by Rexhep Ismaili, Mensur Raifi and Muhamed Kerveshi.

The paradoxical side of this phenomenon happens in Albania, in the transition period, when novels of Milan Kundera entitled "Ridiculous Love" are published." A year later, another publisher with another translator, publishes this book with the title "Joyful Love" and a promotional note: For the first time in Albanian. Yes, this is another issue for another case of comparison and observation.

\section{Kadare in rapport with Shakespeare, Joyce and Orwell}

If Kadare is an indicative measure and representative of modern English literature at a global level (and there is no doubt that this is the case) then it comes as no surprise that scholars of his work, both domestic and foreign, have often placed his name alongside Shakespeare, without excluding Dante, Orwell, Joyce, Kafka and others.

Kadare is little known in English with Chronicle in stone (the version translated by Arshi Pipa) but he is more known with the Successor (not translated from the original in Albanian, but from its publication in French by David Bellos). Obviously, the latest publication of Wrong Dinner (translated by John Hodgson) makes him a place among the honoured. I have not included here a series of Kadare's works published in the U.S., where it is worth mentioning the special edition of the first manuscript edition of the novelist Sol Bellow, only three hundred copies with the authentic paraf author.

In the context of this paper we are interested in Kadare's rapport with the authors mentioned above i.e. Shakespeare, Joyce, and Orwell, of which Shakespeare is the main subject. He appears in Kadare's world since his childhood. Initially Kadare proves this as an artifact in the pages of the novel Chronicle in Stone, when he is faced for the first time with Macbeth, or rather with sorcerers that appear at the beginning of the tragedy, similar to the foretellings of Albanian mythology, which are enough to tempt the imagination of the child. Kadare will prove this later in the interviews as well, but especially in the essayistic book Invitation at the studio and in the essay Hamlet, the tough prince. It is difficult with a paper like ours to assess the rapport Kadare - Shakespeare, given that only this last book, the essay respectively, includes about one hundred and fifty pages of text and it is impossible to pick out whatever citation. It is like trying to take only one stone from a 
castle in order to prove its greatness. Let us take for a test only the first sentence of this work: "It's easy to say that Shakespeare's 'Hamlet' is a universal work... It is harder to answer the question whether this setting is a praise or a blemish". (Kadare. I, HAMLET, THE TOUGH PRINCE, Onufri, Tirana 2006, p. 7). But what he says about Macbeth, in the conversation with Eric Faye, is even greater: "Macbeth actually may have changed my life. I was eleven years old. Why have I read it? While navigating the front pages, I noticed that it had to do with ghosts, sorcerers. I liked mysteries and so I started reading it". (Faye. Eric, THREE CONVERSATIONS WITH KADARE, Onufri, Tirana 2007, p. 18).

Besides Shakespeare, Kadare's creative world is also filled with Joyce and Orwell. While Joyce's epiphany comes to him through his Ulysses and is discussed in Kadare's Monster, the scholars mainly find Orwell in the Palace of Dreams. The analogy here is often associated with Orwell's Animals' farm, as well as with Kafka's Castle.

Despite the fact that, especially Joyce and Orwell, were translated in Albanian very late, Kadare, being in permanent contact with his foreign publishers, especially with the French, got acquainted with their works. Seems like a curiosity to mention the fact that since 1980, when Kadare was in Pristina for the publication of his set of ten works by "Rilindja", in a meeting with Kosovo writers he mentioned Joyce's work Finnegan's awakening, which was until then unheard of in our area. It became clear that it was unimaginable to publish such a work in Albanian while under the rule of the dictator. In Pristina, however, Joyce's Portrait of the artist in youth was published in a secondary language.

\section{Similarities, influences and contextual basis}

As noted above, the similarities and influences of English literature on Albanian literature are outlined more on contextual basis. Furthermore, as noted by De Rada, the impact appears quite spontaneous and almost instinctive. We saw that De Rada didn't prefer Byron, or at least he was not thrilled like he was with Shakespeare. And what happens? There is a surprise. While De Rada has not distinguished himself with recitations of other authors, sometimes while disillusioned he recites his own verses: "Professor, after he approached his classmate Luigj Terci, Paterno asked if those were Byron's verses. - No, - my friend replied, they are his own. The honored old man approached me and, looking at me carefully, after he escorted the students out, he stood next to me". (De Rada. Jeronim, AUTOBIOGRAPHY, Onufri, Tirana 2002, p. 81).

Byron's influence is also confirmed by his scholar, Dr. Abdullah Karjagdiu: "By writing this paper, I had in mind that I had to write not only about the poet that had an extremely large impact on some European literatures of Romanticism period, but, at the same time I had to give special attention to Byron's Albanian inspirations and motives... ". (Karjagdiu. Abdullah, BYRON AMONG ALBANIAN, doctoral Dissertation, Manuscript in the National and University Library of Kosovo. Page 9. Signature to Karjagdiu's voice). Karjagdiu finds Byron's impact primarily on our Renaissance authors and connects it with fundamental notions of love for the country and the missing freedom for Albanians, who were under the captivity of the Ottoman Empire

Noli, on the other hand, relates the influence of Shakespeare's work to similarity situations and contexts. Perhaps led by disappointments he suffered in the political and governing scene of his country, after the failure of the Revolution of July in Albania, in 1924. Therefore in his preface accompanying Macbeth he would write: "A nation, which is disgruntled so much by the terror of the national government, would rather prefer foreign invasion and call it the only salvation, is fatally doomed to lose the political independence." (Shakespeare. William, MACBETH, quoted work, page 8). It is curious that in the translation work, especially of Noli, it was noted, not only the choice of works - masterpieces for translation, which features subjects of interest to literary studies, but also a self identifying affinity of the translators with protagonists or specific characters of those works, also with the situation in the country, namely his homeland.

A special contribution about the effects of English literature in Kadare's work, with exclusive focus to General of the Dead Army, was brought to us by the young scholar dr. Ag Apolloni. He finds influences, especially from Shakespeare, but also from Oscar Wilde, Joseph Conrad and Ernest Hemingway. Let us 
check them out: "Hamlet is the Shakespearean masterpiece which has a grave opening scene ... Literature's most famous tomb is the tomb of Ofelia, so in any literary work we see the opening of a grave, the memory leads us to the grave opened by Shakespeare's clowns. In this way, the General, as he constantly talks about opening graves, constantly reminds us of Hamlet." (Apoloni. Ag, Proteus Paradigm, OM 2012, Pristina, p. 310).

"In communist Albania Oscar Wilde's works were not published because he was considered a decadent writer. But his thinking was paraphrased in Kadare's novel: "I dealt for a long time with them, - the priest replied. - in a place Oscar Wilde says: the people of the lower classes need to commit crimes because crimes give them some strong feelings, which are given to us by the art '. This summarizing may be as a result of author's readings abroad ". (Apolloni. Ag, ibidem, p. 314).

"The General of the Dead Army and Conrad's Heart of Darkness have similarities, especially conceptual ones, of course without claiming that any could be read as invariant, although genetic criticism can find invariants within the stories that precede ... Heart of Darkness and The General of the Dead Army, although written in different centuries, are close, especially in the conceptual field. (Apolloni. Ag, ibidem, p. 315).

Similarities and influences presented by Apolloni are not supported and argumented only in the case of The General, but he sees through the prism of his monographic study. Such refelections are seen throughout Kadare's prose works. He also has a poem titled In Elsinor, which precisely addresses the drama of Hamlet at the castle.

However, it is no coincidence that Kadare quite early brings us Hemingway's novel Old man and the sea in Albanian, without even having mastered English.

From today's perspective it can be said that Albanian and English literatures are no longer two isolated medieval castles, which follow one another from the turrets of the pinnacles of ideological guards, but they are co-residential terrain for writers, for their works respectively, thus paving the proper receiving and giving path that builds the bridge called Relations.

\section{Instead of closure - The future of the Albanian-English literary developments}

As it is already known the anglophone areal stretches on a global dimension, since it is known that in the Albanian world the doctrine of prison monism is destroyed once and for all, since the openness and freedom of communication among Albanian communities across the globe is known, the horizon opens for intercommunication with English culture and literature. If we add to this the institutional insistence in Albania and in Kosovo for the opening of British and American colleges and universities where the younger generation, unlike its predecessors, not individually, but systemic groups, have a chance to pursue studies in different fields of knowledge and art and literature, there is no reason not to increase expectations. Of course, in this respect there is an impact of printed and electronic media, as well as the Internet.

This step would also add mutual recognitions, not only for the top works and authors, but also for other authors, thus bringing special values and originality and creative specifications depending on public opinion and readers' tastes. Lets take just one example. There is almost no Albanian reader, whether only with an average cultural background, not to have read and heard about the rare lyric, Lasgush Poradeci. While in the place of Albanians he holds the throne of Zeus as a poet, outside he is little known or almost not known. Recently he left the Albanian Olympus to join not the English medieval castles, but the modern palaces and departments of literature.

There is a scholar on the horizon, which, as much as he brings curiosity and surprise, he is as also proven by his work and action, especially in the relations of Albanian and English Literature. This scholar is Dr.Anastas Kapurani. As to who is Anastas, it is the Korrieri newspaper that shows us this on Sunday $28^{\text {th }}$ of August 2005, or rather Ben Anthony's interview with him: "Dr. Anastas Kapurani has studied the art of poetry in Greece and then in Indianapolis USA. The fruit of his perennial work is the English edition of Upfront "Myth 
of Lasgush", which is being sold well abroad. The author is attempting to continue his study of poetry later on Kadare's works.

He studied English language in Tirana and used to often see the great Lasgush. Like all students, he feared his part, before the image of the poet-legend. Of course in his lifetime- he could never approach him. Until then, the student of English, who is now Dr. Anastas Kapurani (went through the scientific promotion in Greece and in the United States) followed his magic with eyes. "When I would convince myself to approach him he would leave himself, he says today many years later. He kept this desire suppressed until years later when he went to a graduate literary course... Over the years, he would continue his education for poetry in Greece and in the U.S., while trying to materialize Lasgush's dream, which he no longer had in his head, but in his projects. The fruit of those, which he carried and had studied, was his last study for Lasgush. However, the author does not stop here, but he intends to continue his work with other studies, where first place will definitely be the last of the trio of Albanian literature, Naim Frashëri-Lasgush Poradeci and Ismail Kadare, which he connects with his studies". (http://www.albasoul.com/vjeter/modules.php?op=modload\&name= News\&file=article\&sid=1778).

A constellation of new artists and scholars, who aim literary intercommunication with ambition and willpower, has appeared in Kosovo in recent years. There is no doubt or reserve that the XXI century will be a century of recognition of cooperation between Albanian and English literature.

A couple of years ago, by accident, while I was searching Google for and about literature, I found something that surprised me. In fact a curious reader also appeared there, a passionate Englishman, especially in regards to knowledge about Kaligula. And he, by chance, had found a poem in English titled Horse of Kaligula of the Albanian poet Rudolf Marku. Now, no more information about Horse of Kaligula, but it is precisely the power of poetic art, aesthetic value, the depth of emotion and thought, which made him distribute the poem to his friends as a gift.

This is how I see the future of these relations.

\section{References}

Apoloni. Ag, Proteus Paradigm, OM 2012, Prishtina

Byron. George Gordon, Childe Harold, Onufri, Tirana 1999

Faye. Eric, Three Conversations With Kadare, Onufri, Tirana 2007

De Rada. Jeronim, Autobiography, Onufri,Tirana 2002

De Rada, WORKS 7, "Rilindja, Prishtina 1988,

Durham. Edith, Burden Of The Balkans and other works about Albania and Albanians, Publishing House "Naum Veqilharxhi", Tirana 1998

Kadare. Ismail, Invitation to the Studio, "Naim Frashëri", Tirana 1990

Kadare. I, Hamlet, the tough Prince, Onufri, Tirana 2006

Karjagdiu. Abdullah, Byron among Albanians, doctoral Dissertation, Manuscript in the National and University Library of Kosovo. Page 9. Signature of Karjagdiu's voice

Qosja. Rexhep, History of Albanian Literature, Romanticism I. "Rilindja", Prishtina 1990

Shakespeare. William, MACBETH, "Rilindja", Prishtina 1968

History of Albanian Literature by Robert Elsie, Social Science Monographs, Boulder. Distributed by Columbia University Press, New york 1995

The Angry Cloud - and Anthology of Albanian stories from Yugoslavia, Translated from the Albanian by John Hodgson, Prishtina 1991 